\title{
Migrant Illegality, Nation-Building, and the Politics of Regularization in Canada
}

\author{
JeAn McDonald
}

\begin{abstract}
Regularization, a means for people living with precarious immigration status to legalize or "regularize" their status, is a central demand of immigrant rights groups across Canada. From a perspective of No Borders, does the demand for regularization, while challenging the dayto-day practices of Citizenship and Immigration Canada, also unintentionally reinforce state power? Historical research on regularization programs in Canada suggests that regularization programs do not eliminate migrant illegality but reconfigure it. In this way, regularization may be implicated in processes that both makes and unmakes illegality within the context of immigration and citizenship in Canada.
\end{abstract}

\section{Résumé}

La régularisation, un moyen pour les personnes vivant avec un statut d'immigration précaire de légaliser ou de "régulariser» leur statut, est une revendication centrale de la défense des droits des immigrants partout au Canada. D'un point de vue No Border, la demande de régularisation, tout en contestant les pratiques usuelles de Citoyenneté et Immigration Canada, ne renforce-t-elle pas aussi involontairement le pouvoir étatique? La recherche historique sur les programmes de régularisation au Canada indique que ceux-ci ne suppriment pas l'illégalité des migrants; ils ne font qu'en modifier la configuration. De cette façon, la régularisation peut être impliquée dans des processus qui à la fois font et défont l'illégalité dans le contexte de l'immigration et de la citoyenneté au Canada.

\section{Introduction}

Regularization, a means for people living with precarious immigration status to legalize or "regularize" their status, is a central demand of immigrant rights groups across Canada. But what are the implications of this demand? Coming from a perspective of No Borders, does the demand for regularization, while challenging the practices of Citizenship and Immigration Canada, also unintentionally reinforce state power? Historical research on regularization programs in Canada from 1960 to 2004 demonstrates that the regularization process is a nation-building exercise. "Regularization" is the term most often used by government officials to describe programs that offer opportunities for people living with precarious immigration status in Canada to apply for permanent status. ${ }^{1}$ Regularization programs, however, do not eliminate migrant illegality; instead this illegality is reconfigured through the regularization process. In this way, regularization may be implicated in processes that both make and unmake illegality within the context of immigration and citizenship in Canada.

The theoretical concept and methodological approach of governmentality ${ }^{2}$ is useful for exploring processes of illegalization within the context of immigration policy in Canada. "Illegalization" refers to those processes that make people illegal: processes that illegalize certain bodies in particular spaces within the globalizing nation-state system. In Canada, we can see the ways in which people are made illegal through the classist, gendered, and racist processes of selection and exclusion embedded in the Immigrant and Refugee Protection Act (IRPA). The majority of people living with precarious immigration status in Canada are people who do not meet the restricted requirements of the points system, a system that emphasizes particular work skills and economic status while also privileging an education from white-dominated countries, such as Australia, the US, the UK, and others. Unable to access the points system, many 
have submitted refugee claims or have failed these claims and have decided to remain in Canada rather than face persecution in their country of origin. Others hold work, visitor, or student visas or have overstayed their visas. From a governmentality approach, processes of illegalization-the processes that make a person "illegal"-can be understood as created not solely through state bureaucracies and institutional mechanisms but also through technologies of government. Who should be governing, who needs to be governed, what social practices need governing, all become thinkable and rationalized through social institutions and practices on, and of, the self-not simply through official state policy. One of the techniques of power in this regime of governmentality is the definition of various categories of deviants in opposition to "normal" society.

In Canada, this practice of categorization becomes clear in an examination of regularization programs from 1960 to 2004 . It is through the criteria that determine eligibility for permanent immigration status that definitions of deserving and undeserving applicants become thinkable. The legality of a person, then, becomes thinkable and acceptable through various technologies of government that define and make rational the categorization of deserving migrants as opposed to those deemed "undesirable." This in turn legitimates immigration policy that operates under the anti-immigrant discourse of the need to protect the Canadian national body politic from possible "foreign" contamination, constructing the Canadian nation as valid and pure/purified.

While politicians often consider regularization programs to be a "humanitarian act of a compassionate government" a way to deal with the "problem" of illegal immigrants-historical research complicates this view. From 1960 to 2004, regularization programs have been characterized as onetime-only procedures. Generally coinciding with stricter border controls and increased enforcement, regularization programs often foretell an increase in the production of migrant illegality, as legal channels for migration become minimized and enforcement measures are increased.

Primary research from a project entitled "Non-Status Immigrants: Exploring Models of Regularization," which took place in 2004-2005, ${ }^{4}$ will form the basis of this paper. In this project, the research team, of which I was a part, undertook historical and archival research, as well as conducted key informant interviews, focus groups, and round-table discussions on regularization programs in Canada from 1960 to 2004. In this paper, I will first outline the major regularization programs in Canada from 1960 to 2004 to better understand how regularization programs reconfigure illegality during this time period. In the second section, I examine common criteria for exclusion in the regularization process by posing the question: what are some of the anti-immigrant and racist discourses that have been reproduced through regularization? Through a discussion on the politics of regularization in Canada in the third section, I elaborate on the idea of illegality as a process and expand upon processes of illegalization in the context of immigration policy in Canada.

\section{Regularization: The Making and Unmaking of Illegality}

Within the Canadian context, the term "regularization" tends to be used more frequently than the term "amnesty" by government officials and immigrant rights' advocates alike when describing programs that provide the opportunity for non-status (im)migrants to apply for legal immigration status. Rivka Augenfeld, a long-time community activist and worker with the Jewish Immigrant Aid Services (JIAS) in Montreal, Quebec, notes that government officials are highly averse to using what she calls "the 'A' word"amnesty. ${ }^{5}$ Instead, government officials are far more likely to use the term "review" or "regularization" to describe programs that provide full legal immigration status to those without living without it in Canada. Other immigrant rights' activists, such as Jaggi Singh, point to the politically biased connotations of the term "amnesty" as a form of forgiveness for the supposed wrongdoing of illegal immigration status. ${ }^{6}$ The term regularization, however, has its own connotations similar to that of normalization as understood within a Foucauldian framework-whereby "regular" status means those with legal immigration status, while those without legal status must be "irregular" within this governmental logic.

The Chinese Adjustment Statement Program (1960-1972) is likely the first formal regularization program in Canada. This program allowed for Chinese migrants who came to Canada without status documents, or with the documents of a relative of a Canadian citizen (commonly referred to as "Paper Sons"7), to apply for permanent residency. ${ }^{8}$ Applicants needed to demonstrate that they were of "good moral character" and were not involved in the "industry" of "illegal immigration."9 Chinese communities in Canada were active in pressuring the federal government to change racist immigration laws that had for decades excluded Chinese immigrants, such as the Chinese Head Tax and the Chinese Exclusion Act. ${ }^{10}$ It is estimated that around 12,000 people were regularized through this program. ${ }^{11}$

Following the Chinese Adjustment Statement Program, the Adjustment of Status Program (in French, Operation Mons Pays; in English, also known as "Project 97"12)- the largest regularization in Canada to date-was implemented in $1973 .^{13}$ In the early 1970 s, an increasing number of 
migrants became non-status. This was due, in part, to the 1972 changes in federal immigration policy when Section 34 of the 1967 Immigration Act was repealed. This barred potential applicants from applying for permanent residency from within Canada. ${ }^{14}$ Many community groups and political organizations advocated for a regularization program, and garnered much public support. Despite the narrow time frame-August to October of 1973-tens of thousands applied..$^{15}$ Information about the program was widely disseminated, largely through community organizations. ${ }^{16}$ Although it is unknown how many were excluded or rejected, an estimated 39,000 people were successful. ${ }^{17}$

In 1981, eight years after the Adjustment of Status Program, Haitians living in Quebec fought for and secured a regularization program. By 1980 , more and more Haitians in Canada found themselves with fragile status: they had student or work visas, or perhaps had overstayed their visa and had become "illegal." 18 As the political situation in Haiti worsened, Haitians in Quebec began to organize in order to lobby federal and provincial governments for a program that would address their needs collectively, rather than on a case-by-case basis as refugee claimants. The Office of Christian Haitians played a key role in this struggle as well as in campaigns for regularization in 1972 and 1987. This group first came together when immigration laws changed in 1972-73 and Haitian nationals could no longer apply for permanent residency from within Canada. ${ }^{19}$ This change left many Haitians without legal status, and several non-status Haitians began to be targeted by immigration authorities while attending church. The group organized meetings, lobbied government bodies and officials, and successfully increased public awareness through news coverage..$^{20}$ The 1981 program regularized over 4,000 people. This program rejected applicants with criminal records and serious medical problems. ${ }^{21}$ For example, at least one applicant was refused because he had tuberculosis. ${ }^{22}$ This special regularization for Haitians in Quebec regularized many people; however, for those unknown numbers of applicants who were refused, they were now known to immigration enforcement officials and subjected to increased measures of detention and deportation. ${ }^{23}$

The Minister's Review Committee (1983-1985) was a program in which non-status immigrants who had lived in Canada for more than five years and were deemed to be "successfully established and integrated" could become regularized. ${ }^{24}$ At this time, "illegal immigration" was considered an important political issue by the federal government. Several reports were commissioned by the Canadian Ministry of Employment and Immigration, including two by W.G. Robinson, "Illegal Immigrants Issues Paper" 25 and
"Illegal Migrants in Canada," 26 both of which rejected a general amnesty and recommended conditional settlement and an increase in immigration enforcement and border controls. Through the Minister's Review Committee, an estimated 1,000 people were regularized and an unknown number of applicants refused. So-called "illegal migrants" were considered an important political issue in the early- to mid-1980s, but fell out of political view until around 1994, when the issue of failed refugee claimants from moratorium countries ${ }^{27}$ became prominent.

From 1994 to 1998, the Deferred Removals Order Class (DROC) regularized several thousand failed refugee claimants who had remained in Canada for three years or more without a removal order. ${ }^{28}$ Refused claimants were generally stuck "in limbo" because they were from moratorium countries. Since China was one of these countries during this period, Chinese community organizations in Canada began to advocate for permanent residency for failed refugee claimants. ${ }^{29}$ Groups from Toronto, Montreal, and Vancouver, including many non-status immigrants, drew public attention to this issue. ${ }^{30}$ Approximately 3,000 applicants from China, Iran, and other countries were regularized through this program, but many more were rejected because they did not meet residency requirements, or had criminal records or serious medical conditions. ${ }^{31}$ Four years after the DROC program ended, similar organizing began in Montreal, where failed refugee claimants from Algeria began to mobilize and demand landed status.

In 2002, failed refugee claimants from Algeria mobilized to demand permanent status and secured a regularization program. In the 1990s, many people came to Quebec from Algeria due to the violent conflict that has continued there for many decades. In 1997, the Canadian government stopped all deportations to Algeria as a moratorium country, yet at the same time many Algerians' refugee claims were refused. ${ }^{32}$ In 2002, the Canadian government decided to start deporting people to Algeria again, after a lucrative trade deal was struck between the two countries. ${ }^{33}$ Just over 1,000 failed refugee claimants from Algeria found themselves at risk of deportation. ${ }^{34}$ Many non-status Algerians in Quebec mobilized to put pressure on the government to regularize their status. ${ }^{35}$ They created the Action Committee for Non-status Algerians (CASSA), and worked with allies from No One Is Illegal-Montreal, individual supporters, and various labour, faith, and women's groups. ${ }^{36}$ Forced to act, the Canadian and Quebec governments introduced a regularization procedure for failed Algerian refugee claimants who had been living in Quebec. While approximately 900 people were regularized through this program, over 150 people were refused and continued to face deportation, most because they did not meet the Quebec residency 
requirement, had a criminal record or could not afford to pay the large application fee for the program. ${ }^{37}$

From the internal discussions of Citizenship and Immigration Canada, a preliminary draft document was circulated in September 2001 regarding "Special Measures."38 The objectives of these special measures were to: "Regularize the status of individuals who have established in Canada and are not able to do so through normal procedures"; and "'Clear the decks' for the implementation of new legislation." ${ }^{39}$ Although the "Special Measures" were never implemented before new legislation was introduced with the 2002 Immigrant and Refugee Protection Act (IRPA), many of the recommendations of this circulated document resonate with regularization programs that had occurred in Canada before 2001. For example, a list of factors that meant to guide 2001 deliberations included "Clear criteria that is targeted and exclusive" and a "Specified start and finish date." 40 The criteria explicitly mentioned in the document include a residency requirement of three years, ability to integrate, employment (i.e., not having used public social assistance), and meeting the requirements of medical, criminal, and security checks necessary to be landed in Canada. They would also exclude those who have remained in Canada past the date of their deportation order. Explicit mention is made of the targeted removal of unsuccessful applicants. ${ }^{41}$

Through an historical study of regularization programs in Canada from 1960 to 2004, we can explore the ways in which populations of non-status immigrants become governed and governable. Through this governance, a particular notion of the "good citizen" is created and legitimized. While new citizens, or permanent residents in the case of many regularization programs in Canada, are constructed through the regularization process, the category of the "undeserving immigrant" is simultaneously created, upheld and managed. As such, regularization programs can be understood as being implicated within the processes of illegalization. Illegalization works to both socially exclude, through such practices as detention, deportation, and the closing of legal avenues for entry, and socially include under imposed conditions of exploitability and disposability. As Nandita Sharma argues, immigration policies in Canada tend to uphold a system of global apartheid. 42 "Apartheid" in this global sense does not mean simply the physical exclusion of a group of people from a territorial space; rather, it means their inclusion, via this exclusion, as "illegal" or "unlawful." This categorization ensures the imposed state of exploitability through an erasure of legal personhood for a specified group of people/workers. The "good citizen," as constructed through the regularization process, is largely produced through the criteria that have coincided with every regularization program in Canada from 1960 to 2004.

\section{Criteria for Regularization: Producing/Protecting the National Body Politic}

It [the Canadian immigration system] is an entire apparatus and this system is based on the classification of individuals. ${ }^{43}$

How are the criteria of regularization programs implicated in-and productive of-discourses of racism, nationalism, and the purity-in terms of dominant understandings of the "good citizen"- of the national body politic? In this section, I examine the ways in which the predominant criteria for regularization-criminal inadmissibilities, medical inadmissibilities, attachment to the paid workforce, economic wealth, residency requirements, notions of societal "integration," presence of family, and one's country of origin-produce a specific notion of the "good citizen" and, in so doing, work to govern populations of non-status immigrants in Canada in particular ways. In many ways, regularization programs, as a form of governance, act as a method of categorization, separating those worthy of permanent residency and eventual formal citizenship from those deemed unworthy or dangerous to the national body politic, creating justification for their detention and deportation.

Criminal inadmissibility, among the most common criteria used to exclude people from regularization programs, is implicated in an insidious and racist discourse that produces some migrants as a source of fear and danger who must be "screened" in order to prevent their "contaminating" the national body politic. Not surprisingly, criminality tends to be the most controversial element in the demand for regularization by immigrant rights groups. Some advocates of regularization still accept this criterion as important and acceptable. However, by accepting criminality as a legitimate basis of exclusion, there is a denial of the systemic and institutional racism, which has been well-documented as existing within the Canadian policing and the criminal justice system. ${ }^{44}$ In particular, it denies the criminalization of racialized and poor communities, which in turn upholds the prison-industrial complex. For example, several participants in focus groups with non-status immigrants in Toronto pointed out that this condition does not address systemic racism, classism, and sexism within policing and the criminal justice system in Canada and in their countries of origin. A middle-aged woman of colour who had lived in Toronto for several years employed as a domestic worker with precarious status demonstrates this concern:

You shouldn't be punished again after you've served your time. Plus, not everybody really commits a crime. There's a big problem with false imprisonment and unfair judges. And today is a very stressful world we live in; people make mistakes. ${ }^{45}$ 
In this statement, this woman is making two important points. The first is that facing deportation after a person "serves their time" in prison imposes a double punishment. The second point is that criminal justice systems are not infallible.

Many non-status immigrants and community activists have also argued that criminal inadmissibility is unfair on the basis of double punishment. As a non-status activist in Montreal pointed out, "We're humans, we're individuals. And if an individual did some kind of gesture that is criminal then they can be punished through the justice system. Why specifically target a whole set of human beings based on these criteria, for who they are?" 46 Thus, people with precarious forms of immigration status, including permanent residency, could "serve their time" in jail, but then face deportation afterwards. Formal citizens, on the other hand, would only have to "serve time" and are therefore only punished once.

Historically, regularization programs have also excluded people with serious medical conditions. Like criminality, this criterion is implicated in a nationalist production of fear, and reinforces the discourse that constructs immigrants as potentially dangerous and diseased-thus needing to be screened, tested, monitored and contained by the state. This criterion is also legitimated through a discourse emphasizing cost analysis, wherein people with illness are considered to be undeserving of permanent residency because they act as "drains" on the Canadian system. Many people with precarious status described exclusion on medical grounds as extremely problematic, discriminatory, and inhumane. A domestic worker of colour with precarious status pointed out, "People who are ill should be treated equally with others." ${ }^{7}$ Several people I spoke with noted that many precarious immigrants get sick as a result of the unsafe and dangerous work conditions that they are forced to accept in Canada. For example, one woman employed as a domestic worker pointed out, "Sometimes you get the disease here and they want to send you back to your country. That's not right." ${ }^{3}$ Another explains, "The job that you get as a non-status immigrant is a job that is going to get you sick." ${ }^{2}$ People with physical disabilities, or who have chronic illnesses such as kidney disease, HIV/AIDS, leukemia, or tuberculosis, are often found "medically inadmissible" for permanent residency, whether through regularization, sponsorship, or Humanitarian and Compassionate applications.

People's attachment to the paid workforce and their economic worth have also been used to exclude certain people from regularization programs, either because of the work that they do or because of their inability to financially support themselves and their families. Exclusion based upon one's economic stability is similar to medical inadmissibility in that both depend upon a cost analysis discourse for their legitimacy. Furthermore, a cost analysis discourse constructs a false dichotomy between Canadian-born citizens, who in this framework maintain a valid claim to medical care and social welfare outside of the criteria established for (im)migrants, and migrant "outsiders," who purportedly have not "paid their dues" and may not access these services.

In reality, however, people with precarious immigration status do pay taxes, and often perform the underpaid and unwanted work that underpins the Canadian economy. A fitting example is the work performed by domestic workers, whether through the Live-In Caregiver Program (LCP) or in the informal economy. Due to the gendered nature of childrearing labour in Canada, this work allows many Canadian women to pursue paid work outside the home and lets the Canadian government avoid the cost of a nationally subsidized child care strategy. The discourse of cost analysis also insists on producing people as "drains" upon the Canadian system rather than recognizing a person's essential worth as a human being and the multiple ways in which people may enrich the world in which they exist. As a Spanish-speaking woman from Latin America argues,

All of us work in some form. The woman works in the house, the children work towards the future, because studying is a form of working. We all give many, many things back to the country. For this reason, it doesn't seem fair [to exclude people who are not formally employed] ... everyone works. ${ }^{50}$

With this statement, she is insisting that all members of a community hold intrinsic value within that community, regardless of cost analysis arguments that especially target (im)migrants to the contrary. The general sense of all focus groups with non-status immigrants in Toronto was that people who cannot always do paid work (for example, people with disabilities, single mothers, elderly people) should not be excluded from regularization programs. Exclusion on the basis on lack of employment does not take into account that many people have to live with restrictions that limit their ability to access paid labour.

Community activists and non-status immigrants alike criticized regularization programs that would only allow applicants to obtain temporary work permits, such as the one proposed by the Greater Toronto Home Builders' Association (GTHBA) and the Construction Recruitment External Workers Services (CREWS), ${ }^{51}$ because they cannot provide the security and stability that permanent residency offers. As a front-line worker at a counselling and settlement centre noted, 'I've had people who've done these 
work permits and they think they're legal. No-in two years time you're going to have to renew." 52 Commenting on temporary work permit programs, a Spanish-speaking woman originally from Latin America with precarious status stated:

This certainly seems like a double-edged sword to me. Because they tell you something, but it has a double meaning. And the double meaning is that they're going to attract and tempt you [to make yourself known, to apply], and they're not going to pass or accept everyone. So, you give or send them all your information, and then when they get to your case they might or might not give it to you. So to me this seems like a double-edged sword; it does not work for me, nor for my family, nor for my friends ... My choice-what I would like-is a definitive thing, that is not something where for 3 or 4 years I am calm, and then I only have two months before I return to being driven crazy again. And I face the same risks again ... So for me it needs to be definitive, for today and for the future. ${ }^{53}$

In this statement, this woman is drawing attention to the need for a regularization program that does more than simply legalize and identify workers within a limited time frame. As she points out, there is little to gain and a lot to lose for non-status immigrants who make themselves known and identifiable to immigration enforcement authorities without at least the chance of gaining permanent residency. As well, people holding work permits are generally dependent on a valid contract with an employer, leaving workers who may have work permits but do not have permanent residency open to abuse by employers. ${ }^{54}$ Work permits simply do not address the long-term needs of non-status workers and their families.

Residency requirements are another means of exclusion from regularization programs. An example of this criterion would be requiring applicants to have resided in Canada for a particular period of time or to have arrived in a certain location before a certain date, such as in the case of the 2002 regularization for Algerians residing in Quebec. Like criminal checks and medical conditions, this requirement is implicated in an exclusionary nationalist discourse that demands loyalty and proof of belonging from those viewed as outsiders or foreign to the national body politic. Several people with precarious status that participated in our research argued that length of residency should "count for something." For instance, one Portuguese-speaking woman originally from Brazil argued, "The amount of time that a person worked and lived decently, that you worked, paid taxes, were involved in the community, that you were in the country all counts." 55 However, others argued that everyone should be included in a regularization program, [or at the very least accounted for while waiting to meet the residency requirements, if there is a minimum amount of time one must have been living in the country before they are eligible for permanent residency], "During that time the person should be given some kind of security in order to live here. For example, if you go to the bank [without legal status] you are told you cannot open an account because your SIN starts with a 9." 56 One woman responded, saying, "Perhaps during that time the person should be given a permit to prove to Canada that you can be useful. After those three years then you should be given your papers. It is important to have some kind of stability during that time." 57 Another Spanish-speaking woman with precarious status pointed out people who are deported after living in Canada for many years often experience removal as traumatic:

Why does Canada not see the situation of the children of the people who live here? After three or four years the child here learns the language, learns the customs and then to return him back to his country of origin does very strong damage. It is a psychological damage. ${ }^{58}$

As indicated in this statement, long-term non-status residents of Canada living with the condition of deportability often experience removal in a dual sense: physically, from the national territory, and psychologically, as this woman points out, from the national body politic and, therefore, also they are removed and excluded from a sense of national belonging. In sum, residency requirements, whereby applicants must prove residency in Canada for a certain number of years, serve to keep people with precarious immigration status in a state of "illegal limbo" in which exploitation by employers, landlords, and others can continue as long as vulnerability to the twin disciplinary practices of detention and deportation remain.

Having family members living in Canada has also been used as a common criterion in regularization programs. People with precarious status as well as community agency workers have argued that the definition of family in the Canadian immigration system is narrow and exclusionary. Countering the narrow definition of family used by Citizenship and Immigration Canada, one woman of colour from the Caribbean defined family as "anybody in the community who has helped you and stood by your side."59 Another woman with precarious status noted, "Most people come here without any family." ${ }^{\prime \prime}$ Furthermore, the Canadian immigration system tends to privilege the patriarchal hetero-nuclear family, while queer, single parent, and non-nuclear families are likely to be excluded, whether officially or informally. As a community health centre worker noted: 
Issues around sexuality and sexual orientation are almost never mentioned in these kinds of policies. The level of closeting and fear that people face in order to hide their sexual orientation and try to 'get in' as a straight person, is just ... We don't even know how much that's going on. ${ }^{61}$

Heterosexuality is often presumed as the norm in many immigration policies, such as the family sponsorship program-and regularization programs are no exception. Similarly, the application process is gendered as it tends to be centred on the "man of the family." As one worker at a neighbourhood centre pointed out, "Immigration is very patriarchal, and they always assume that the man is going to be the principal applicant. So then it's in the hands of the man to be responsible for [his wife], and it's like a favour for her." 62 The criterion of family, and the often patriarchal, heterosexist assumptions plaguing immigration policies in general, can be understood as another way in which women, trans, and queer migrants may be excluded within a regularization program.

Regularization programs have at times also included "integration" as a central criterion for eligibility. Some people with precarious status thought that this was, in some ways, a fair condition. At the same time, many also pointed out that due to time constraints it can be difficult to get involved in activities that are generally associated with integration, such as the learning of one of the two official languages of Canada (English or French), going to church and volunteering with community organizations. One participant summarized this by saying that after working many hours of overtime and looking after your family, "there is very little time left for integrating." 63 One woman rejected the criterion of "integration" altogether, saying, "Who cares how well you get along! People are people." 64 The criterion of "integration" can be understood as largely discretionary and arbitrary. Community workers and immigration legal workers pointed out in interviews that immigration officers will often decide what "integration" means on a case-bycase basis.

Several regularization programs in Canada have focused on a particular group of people coming from a specific country. When discussing the criterion of country of origin, many people with precarious status pointed out the systemic racism within the current immigration system, whereby certain groups of people (e.g., white immigrants from the UK) tend to be treated differently than other groups of people (e.g., Black immigrants from the Caribbean). As one woman said: "We [Black immigrants from the Caribbean] are treated differently. And they [white British immigrants] act as if they're born here." 65 Others mentioned that many people escaping violence and persecution are not recognized as refugees because the Canadian government has decided ahead of time that their countries are not dangerous. For instance, one woman pointed out,

Because you come from the Caribbean, they just look at you and say how can you be a refugee? I'm suffering and I'm struggling, and I'm being battered and abused and mistreated and raped and everything you can think of but my country doesn't show up on the list. ${ }^{66}$

This statement highlights the precarity of temporary status in Canada, especially as one moves from the relative stability of the position of refugee claimant to that of a failed refugee claimant who will likely face removal procedures in the near future. This example points to the failure of the refugee determination system to recognize many people who come to Canada seeking refuge as political refugees, especially when they are seeking refuge from a nation-state with which Canada has lucrative economic relationships. Most participants felt that a regularization program should accept applications from all non-status immigrants on an equal basis, regardless of their country of origin.

Distinguishing the criminal from the good, the diseased from the healthy, the lazy from the hard-working, the newly arrived from the loyal, those who do not belong from those who do belong, the regularization process is a nation-building practice. Not only are the purportedly "weak" sorted from the "strong" applicants, the national body politic must be protected from those deemed "unsuitable" subjects within the national territory. The technologies of detention and deportation are used to further contain and remove rejected applicants. Yet, they are also used as disciplinary tactics within a system in which precarious or "illegalized" immigrants are legally and systematically denied access to the rights and entitlements that fully legal residents of Canada are afforded thereby enforcing an erasure of their legal personhood and attempting to limit their social and political participation within the social spaces of illegality.

\section{Illegality and the Politics of Regularization}

How do people become illegalized in Canada? Illegality can be better understood when examined as the product of a set of processes rather than as a given state or status. As demonstrated above, regularization programs are one of several processes that produce and reconfigure illegality in the context of immigration in Canada. While the flow of migratory labour tends to be understood and produced through state policies and practices as the sole responsibility of the individual, conditions of poverty, unemployment, displacement, and other consequences of capitalist globalization should 
be recognized as central factors of global migrations. ${ }^{67}$ As a refugee agency worker pointed out:

It's also a situation of the contradiction between growing global inequalities and tightening borders ... There's the situation of undocumented people already here, but there's the ongoing process as well, of migratory pressures and how you get in if there aren't any legal avenues for people. If you don't fit the refugee definition, maybe they're not life-threatened in a political way but they're life-threatened because their social rights are not protected in their country of origin. ${ }^{6}$

A woman with precarious status described an example:

I know a case of a woman with two children. She applied for [refugee status] and they were denied but the children are studying here, they speak the language. That family is illegal. Do you think that is legal? Can Canada really say that it is one of the countries with more humanitarian sense? That person worked, paid taxes, all that she wanted was an opportunity because in her country she was a victim of domestic violence. She came here to give her children a better life. ${ }^{69}$

Sassen argues that large-scale global migrations are structured through various transnational and geopolitical processes (including colonial and de facto colonial relationships) that can only be partially regulated through national immigration controls. ${ }^{70}$ With this understanding, we can see how global migratory flows become one of the processes of illegalization in Canada. Sassen points out that because global migratory flows occur regardless of national immigration controls, fears of a "control crisis," or the "flooding" of migrants into a national territory, are largely unwarranted. ${ }^{71}$ This indicates that migrants will arrive in Canada regardless of legal avenues for entrance. As Sassen notes, when one avenue of legal entrance is closed off or minimized, numbers will increase via other channels. ${ }^{72}$ Changes in immigration policy, such as the repeal of Section 34 of the 1967 Immigration Act in 1972 that barred potential applicants from applying for permanent residency within Canada, have led to an increase in people losing opportunities for full legal immigration status. Since regularization programs have tended to coincide with the tightening of legal avenues of entrance and increased measures of immigration enforcement, the implication is that the population of migrants entering through illegal or semi-legal channels (e.g., visa-holders who will stay after visas expire; failed refugee claimants who remain in Canada) will likely increase.

The consequences of global capitalism, such as displacement, poverty and unemployment, are among the driving forces behind global migration. Global capitalism is, in many ways, dependent upon a system of global apartheid, and this global apartheid is reproduced through global migrations. Sharma calls into question whether citizenship regimes are simply exclusionary; instead she examines the tendencies of a nation-state system of global apartheid to include via an exclusionary framework. She writes, "[L]ike past forms of apartheid, global apartheid is not based on keeping differential people apart but instead, on organizing two (or more) separate legal regimes and practices for differentiated groups of people within the same space." 73 The existence of global apartheid is often denied, Sharma argues, because it continues to be associated with "race"-based legal differentiations and there are almost no legally based "race" distinctions found in immigration law today. The nationstate system of global apartheid, however, legitimizes both global inequalities and the use of coercive force, such as detention and deportation, against non-citizens and also naturalizes classed, gendered, and racialized exclusions to national membership. ${ }^{74}$ One of the effects of this system of global apartheid is the establishment of a hierarchical system in which access to rights and entitlements become based upon categorizations of more- and less-deserving migrants. Sassen points out that the relationship between the global economy and the nation-state is not one of opposition or mutual exclusivity; instead, the nation-state system is an essential element in the development of capitalist globalization. ${ }^{75}$ As one of the processes of illegalization, global migrations also function to fulfill the needs of the national economy-satisfying the demand for cheap, exploitable, and disposable labour. As a member of the Action Committee of Non-Status Algerians explained,

Canada is a country built on immigration. One thing is clear: the Canadian government understands this and understands that its economy needs the pool of illegal workers, its temporary workers; it brings in a lot of money. Immigrants in general are bringing in a lot of money. ${ }^{76}$

In conversation, two women with precarious status point out:

A. There is a lot of propaganda in South America that Canada wants to bring immigrants. Why, instead of bringing more people, doesn't it regularize everybody that is already here? There are people who are already working and giving to the country.

B. At the same time because they do not give us documents they make us lie. Then you have to use someone else's social [Social Insurance Number]. ${ }^{77}$

A system of global apartheid, necessary to the demands of global capitalism and serving the needs of the Canadian 
national economy, is both productive of and dependent upon processes of illegalization.

Immigrant rights' advocates have sought to change the policies and practices of the immigration system within Canada as demonstrated above in regard to regularization programs. Currently, immigrant rights' activists tend to point to inadequacies within the refugee determination system and the lack of viable options for non-status immigrants to obtain permanent residency. At present, the only procedure that allows non-status immigrants in Canada to apply for legal immigration status is to make an application on Humanitarian and Compassionate ( $\mathrm{H} \& \mathrm{C}$ ) grounds for landed status. With an estimated 5 per cent success rate for applicants, according to the community workers and migrant justice activists I spoke with, this program is not acceptable to many immigrant rights' groups because it does not offer an adequate solution for people living and working in highly exploitable and vulnerable conditions. The $\mathrm{H} \& \mathrm{C}$ application focuses predominantly on integration, having family members in Canada, and paid employment. Automatic inadmissibility found through medical, criminal, and security checks denies many potentially successful candidates the opportunity to obtain legal status. For example, Avvy Go, a lawyer with the Chinese Canadian Legal Clinic in Toronto, ON, noted that a common medical problem that makes people inadmissible for landed status is kidney disease:

Kidney [disease] is just one example ... [one client] had a positive $\mathrm{H} \& \mathrm{C}$, but was not landed because of medical [criteria], right? So by then his kidney is getting even worse. He needs a transplant. So, they [Citizenship and Immigration Canada] know that if he goes back to China he will die because he's not going to get a transplant. That's part of the reason why they allow him to stay on $\mathrm{H}$ \& C grounds. But then they can't land him because of a medical problem, right? Why is that fair, why is that a criteria, knowing that this person otherwise meets all the criteria that is set up? ${ }^{78}$

Another avenue for permanent residency from within Canada is through a refugee claim. However, a major flaw recognized within the Immigrant and Refugee Board (IRB), the governmental bureaucracy that makes decisions on both claims for permanent residency on humanitarian and compassionate grounds and claims for refugee status, is the lack of an "in-person" appeals process for refugee claims. This is despite the fact that under the 2002 Immigration Act the implementation of a Refugee Appeals Division is required by law. In other words, an appeals process in set out in policy but has yet to be institutionalized in practice.
As a worker at a community health centre pointed out, many of the current policies of Citizenship and Immigration Canada produce migrant illegality because people "fall through the cracks" of the current system:

It's our current immigration law that makes a lot of people fall through the cracks and become undocumented in the first place, so if you're sort of abiding by the same criteria, there are lots of people that are going to fall through the cracks [of the regularization process]. ${ }^{79}$

A significant consequence of policies implicated in the production of processes of illegalization is that people who "fall through the cracks" are then "socially include[d] under imposed conditions of enforced and protracted vulnerability." 80 Immigration policy, due to the need to sort and classify populations of migrants, is a process of illegalization. The current governmental organization of the immigration system, then, is in itself productive of migrant illegality.

De Genova writes, "The social space of 'illegality' is an erasure of legal personhood-a space of forced invisibility, exclusion, subjugation, and repression." 81 Thus, illegality is a spatialized condition in which the physical borders of the nation-state are reproduced within the everyday lives of racialized immigrants in countless locations. ${ }^{82}$ For example, a Toronto Star article reports that federal immigration officers with an order to deport acted to remove children who were attending two Toronto schools in April 2006. In one of these cases, the effect of the officers' action was to force the children's parents out of hiding. ${ }^{83}$ Another article reveals that when immigrant women without full legal immigration status in Canada attempt to press charges on abusive partners, they often face detention and deportation. ${ }^{84}$ These examples allude to a process of illegalization manifested in policies, codes, regulations, and practices in which state borders are revealed within the territorial borders of the nation-state. As Sharma has pointed out, the border is not just a physical geographic territorial marker. ${ }^{85}$ Instead, the border exists wherever non-status immigrants may come into contact or confrontation with institutional settingswhether enrolling children in school, stopped for a traffic violation by police, or asked for a SIN card when applying for a job. This is an ideological border that arises, emerging as widespread and ever-present, when people try to access social services such as heath centres, social housing co-operatives, schools, food banks, welfare offices, police stations, and others. Ideological borders function within and beyond the scope of citizenship to make the whole of a person, in effect, illegal. As such, borders (both physical and ideological) affect not only one's legal and political 
"rights," but are also implicated in notions of who "belongs" and who does not. ${ }^{86}$

\section{Conclusions}

The history of regularization in Canada from 1960 to 2004 demonstrates the ways in which migrant illegality is reconfigured through immigration policies such as regularization programs. Migrant illegality is produced when people are categorized through the eligibility criteria historically associated with regularization. Thus, the so-called "problem of 'illegal' migrants" is not "solved" in any long-term sense but rather managed through the differential categorization of migrant populations as those deemed desirable and those deemed undesirable-with the desirability of an applicant determined through the use of strict criteria. The act of producing the "good citizen" through regularization, then, cannot be separated from the production of illegality in those persons excluded from the regularization process. Excluded from the nation, those who are rejected are often subject to increased and intensified measures of immigration enforcement, such as detention and deportation. These heightened enforcement measures often ensure the swift physical exclusion of undesirable applicants. Meanwhile, threats of detention and deportation maintain the enforced inclusion of non-status immigrants through conditions of exploitability and the disposability.

In Canada, regularization programs have historically been implemented through the use of strict criteria, such as criminality, medical health, employment, residency, integration, family, and country of origin, among others. De facto criteria such as economic wealth, racialization, and discrimination against anyone deemed to not be heterosexual also come into play through application fees, and the consideration and evaluation of such criteria as "integration" within Canadian society and the co-residence of those defined as "family" in Canada. It is thus through both explicit and implicit criteria that applicants become excluded from regularization programs. Regularization programs, through the application and evaluation processes, produce and reproduce xenophobic and nationalist discourses. The immigrant becomes constructed as a source of fear, danger, and disease; as something to be screened, tested, monitored, contained, and deported in order to ensure the health of the national economy and to prevent the contamination of the national body politic.

Despite the risks involved in advocating for a regularization program, the demand for "status for all" remains one of the key struggles of many immigrant justice organizations across the country, including No One Is Illegal (in Vancouver, Toronto, Montreal), the Solidarity Without Borders coalition (Montreal), and several others. Yet, to advocate for a regularization program is to participate in a nation-building exercise; to ask the state to reassert itself and make decisions about who is desirable and who is undesirable. On the other hand, a regularization program would have a huge impact on the lives of possibly tens of thousands of people who would no longer have to live with the twin threats of detention and deportation.

One way that migrant justice activists have addressed this concern with regularization is to work towards "Don't Ask, Don't Tell" or "Access without Fear" policies within municipalities, demanding that city services be made available for all residents regardless of their immigration status. This follows in the footsteps of several campaigns in the US that have created "sanctuary cities" to varying degrees. Cities across the US have adopted variable resolutions that in many ways challenge federal immigration laws; indeed, some have referred to themselves as "sanctuary cities" or "safety zones." 87 Over fifty cities have passed legislation that forbids the use of municipal funds, resources, and workers for the enforcement of federal immigration laws. Others, such as Los Angeles, Chicago, Portland, Seattle, New York City, and Minneapolis, to name a few, have taken more proactive roles, whereby specific legislation bars city workers from inquiring into and/or disseminating immigration information regarding persons using city services. ${ }^{88}$ Resolutions passed in Baltimore, Austin, Cambridge, and other cities affirm that no city service will be denied on the basis of formal citizenship status. ${ }^{89}$ These changes in municipal policy were not "granted" by municipalities; rather, these transformations were hard-won by immigrants, refugees, and their allies through hard work, research, networking, and advocacy. These campaigns work towards creating communities that are not dependent upon formal citizenship as a marker of belonging.

Through such practices, the social space of migrant illegality, while certainly not abolished, is remade through the establishment of (porous) city boundaries. Municipal policies affirming the right to public services for all members of the metropolis pose an important challenge to state definitions of "illegality" in the context of immigration status. As noted above, the physical borders of the state are reproduced in countless scenarios within the territory of the nation-state. Many of these situations wherein borders are frequently reproduced-attending school, going to the hospital, applying for social housing, accessing emergency shelter services, and calling for police assistance-would be circumvented to a great extent through a municipal policy that rescinds discrimination based on immigration status and ensures access to services without fear of immigration enforcement measures. 
At the same time, however, it is important to recognize the very real impact that access to formal citizenship has on people's everyday lives. As Monica Varsanyi points out, "the legal right to remain must not be considered insignificant." (emphasis added) ${ }^{90}$ Even within a city that affirms access to city services regardless of formal citizenship, federal authorities are not barred from enforcing federal immigration laws-arresting, incarcerating and deporting those persons not deemed acceptable within the national body politic. The demand for a regularization program and the movement towards "sanctuary cities" are two vital goals within the migrant justice movement in Canada, yet both have with significant limitations. Activists and scholars concerned with migrant rights can also examine the ways in which systems of immigration selection are systems of hierarchical classification that, in turn, uphold a system of global apartheid and global capitalism. The vital goals of "status for all" and "sanctuary cities" must not be understood as an end to a radical politics of immigration, but only a beginning in a long-term fight for global justice, freedom of movement, and a rejection of the nation-state system, one that must be taken up within the contexts of colonialism in which they emerge, and with a commitment to indigenous solidarity.

\section{Notes}

1. From 1960 to 2004, successful applicants to regularization programs were accorded permanent residency. At present, however, most discussions by government officials around the idea of regularization have generally focused on the allocation of temporary work permits. See, for instance, Gray, "City Considers Asking Ottawa to Let Illegals Who Are Working Stay," Globe and Mail, March 30, 2005, about discussions in City of Toronto council to push for a "regularization" that would accord successful applicants temporary work permits.

2. M. Foucault, "Governmentality," in The Foucault Effect, ed. G. Burchell, C. Gordon, and P. Miller (Chicago: University of Chicago Press, 1991); C. Gordon, "Governmental Rationality: An Introduction," in The Foucault Effect, ed. G. Burchell, C. Gordon, and P. Miller (Chicago: University of Chicago Press, 1991); A. Ong, Buddha Is Hiding: Refugees, Citizenship, the New America (Berkeley: University of California Press, 2003).

3. E. Khandor, J. McDonald, P. Nyers, and C. Wright, "The Regularization of Non-Status Immigrants in Canada 1960-2004: Past Policies, Current Perspectives, Active Campaigns" (Toronto: Centre of Excellence for Research on Immigration and Settlement (CERIS), 2004).

4. Funded by the Centre of Excellence for Research on Immigration and Settlement (CERIS), the Globalization and Autonomy Project, and McMaster University.
5. Rivka Augenfeld, interview by Jean McDonald for "NonStatus Immigrants: Exploring Models of Regularization" project, Montreal, PQ, July 3, 2004.

6. Montreal Non-Status Activist Roundtable (group of representatives from immigrant rights' organization, predominantly non-status activists), facilitated by Jean McDonald and Jaggi Singh for "Non-Status Immigrants: Exploring Models of Regularization" project, Montreal, PQ, October 16, 2004.

7. A. Go, "The Broken Dream of an Immigrant without Status" (Toronto: OCASI, 2002).

8. Permanent residency in Canada is not permanent per se. If a permanent resident is convicted of a crime for which the maximum sentence is ten years or more (regardless of the time actually served), after undergoing penalty for the crime, the person loses their status as a permanent resident and will likely face deportation. More recently, permanent residency cards have been introduced. These cards must be renewed every five years; in order to renew, a detailed history of where you have lived, where you have worked, and other aspects of your life must be supplied to Citizenship and Immigration Canada.

9. Applied History Research Group, "Adjustment Statement Policy," in The Peopling of Canada 1946-1976, ed. Applied History Research Group (Calgary: University of Calgary, 1997).

10. Victor Wong, interview, August 26-27, 2004.

11. Applied History Research Group.

12. W. G. Robinson, "Illegal Migrants in Canada," ed. Ministry of Employment and Immigration (Ottawa: Government of Canada, 1983).

13. Jean-Claude Icart, interview, October 18, 2004.

14. Ibid.

15. F. Hawkins, Critical Years in Immigration (Kingston: Queen's University Press, 1991).

16. Icart.

17. A. Go, "History of Canada's Immigration Law" (Toronto: Metro Toronto Chinese and Southeast Asian Legal Clinic, 2004).

18. Icart

19. Ibid.

20. Ibid.

21. Ibid.

22. Ibid.

23. Ibid.

24. Go, "History of Canada's Immigration Law."

25. W. G. Robinson, "Illegal Immigrants Issues Paper," ed. Ministry of Employment and Immigration (Ottawa: Government of Canada, 1983).

26. Robinson, "Illegal Migrants in Canada."

27. Canada imposes a moratorium on removals to countries which the Canadian government deems insecure, generally due to political turmoil such as civil war or coup détat.

28. Wong.

29. Ibid. 
30. Ibid.

31. Ibid.; Avvy Go, interview, July 5, 2004.

32. M. Lowry, and P. Nyers, "Round Table Report: 'No One Is Illegal': The Fight for Refugee and Migrant Rights in Canada," Refuge 21, no. 3 (2003).

33. S. Montgomery, "Tears Linked to Water Deal? Deportation Seems to Make No Sense. Big Water Contract Was Announced about the Time Canada Decided Algerians Should Leave," Montreal Gazette, 19 October, 2002; Montreal Non-Status Activist Roundtable, Roundtable Discussion, October 16, 2004.

34. Lowry and Nyers.

35. Montreal Non-Status Activist Roundtable.

36. Ibid.

37. Lowry and Nyers.

38. Government of Canada, "Special Measures" (Ottawa: Citizenship and Immigration Canada, 2001).

39. Ibid.

40. Ibid.

41. Ibid.

42. N. Sharma, "Immigration and Global Apartheid" (public lecture, No One Is Illegal Community Action Forum, Toronto, ON, 2005).

43. Member of the Action Committee of Non-Status Algerians, Montreal Activist, 2004.

44. V. Satzewich, Racism and Social Inequality in Canada (Toronto: Thompson Educational Publishing, 1998); G. T. Williams, "Racism in Justice: The Report of the Commission on Systemic Racism in the Ontario Criminal Justice System," in $(A b)$ Using Power: The Canadian Experience, ed. S. C. Boyd, D. E. Chunn, and R. Menzies (Halifax, NS: Fernwood Publishing, 2001); G. T. Williams, "Sentencing Black Offenders in the Ontario Criminal Justice System," in Making Sense of Sentencing, ed. D. Cole and J. Roberts (Toronto: University of Toronto Press, 1999).

45. Non-Status Women of Colour Focus Group, Focus Group Discussion, August 14, 2004.

46. Montreal Activist Roundtable.

47. Non-Status Women of Colour Focus Group, August 14 2004.

48. Ibid., July 102004 .

49. Ibid., August 142004.

50. Non-Status Spanish-Speaking Women Focus Group, Focus Group Discussion, July 24, 2004, translated into English from Spanish.

51. Greater Toronto Home Builders Association and Construction Recruitment External Workers Services, "Proposal to the Government of Canada to Regularize Undocumented Workers in the Residential Construction Sector" (Toronto: Greater Toronto Home Builders Association, 2003).

52. Community Agency Workers' Roundtable, Roundtable Discussion, September 28, 2004.

53. Non-Status Spanish-Speaking Women Focus Group, August 14, 2004.
54. Refugee agency worker, Community Agency Workers' Roundtable, Roundtable Discussion, September 28, 2003.

55. Focus Group of Non-Status Portuguese-Speaking Women, Focus Group Discussion, July 24, 2004, translated into English from Portuguese.

56. Spanish-Speaking Women Focus Group, August 14, 2004. The Social Insurance Number (SIN) begins with a "9" to indicate that the cardholder is a "temporary foreign worker." SIN cards beginning with a "9" also have an expiry date corresponding to the date to which the cardholder is legally entitled to work.

57. Ibid., July 24, 2004.

58. Ibid.

59. Women of Colour Focus Group, July 10, 2004.

60. Ibid., August 14, 2004.

61. Community Agency Workers' Roundtable.

62. Ibid.

63. Women of Colour Focus Group, July 10, 2004.

64. Women of Colour Focus Group, August 14, 2004.

65. Ibid.; Canadian Council for Refugees, "Report on Systemic Racism and Discrimination in Canadian Refugee and Immigration Policies" (Toronto: Canadian Council for Refugees, 2001); L. Jakubowski, Immigration and the Legalization of Racism (Toronto: Fernwood, 1997).

66. Women of Colour Focus Group, July 102004.

67. S. Sassen, Losing Control? Sovereignty in an Age of Globalization (New York: Columbia University Press, 1996).

68. Community Agency Workers' Roundtable.

69. Spanish-Speaking Women Focus Group, August 14, 2004.

70. Sassen.

71. Ibid.

72. Ibid.

73. N. Sharma, "Global Apartheid and Nation-Statehood: Instituting Border Regimes," in Nationalism and Global Solidarities, ed. J. Goodman and P. James (London: Routledge, 2007).

74. Ibid.

75. Sassen.

76. Montreal Activist Roundtable.

77. Spanish-Speaking Women Focus Group, August 14, 2004.

78. A. Go, interview, July 5, 2004.

79. Community Agency Workers' Roundtable.

80. N. De Genova, "Migrant 'Illegality' and Deportability in Everyday Life," Annual Review of Anthropology 31 (2002): 429.

81. Ibid., 427.

82. Ibid.

83. T. Kalinowski, "Boards Attack Removal of Kids: Students Used to Lure Parents," Toronto Star, May 1, 2006.

84. N. Keung, "Women Face Dilemma: Abuse or Deportation?" Toronto Star, August 3, 2004.

85. N. Sharma, "On Being Not Canadian: The Social Organization of 'Migrant Workers' in Canada," Canadian Review of Sociology and Anthropology 38, no. 4 (2001).

86. Ibid. 
87. National Immigration Law Centre, "Annotated Chart of Laws, Resolutions and Policies Instituted across the U.S. Against State and Local Police Enforcement of Immigration Laws" (Los Angeles: National Immigration Law Centre, 2004).

88. Ibid.

89. Ibid.

90. M. Varsanyi, "Interrogating 'Urban Citizenship' vis-à-vis Undocumented Migration," Citizenship Studies 10, no. 2 (2006).

Jean McDonald is a doctoral candidate in the graduate program in Social Anthropology at York University and a longtime member of No One Is Illegal in Toronto.

(C) Jean McDonald, 2009. This open-access work is licensed under a Creative Commons Attribution-NonCommercial 4.0 International License, which permits use, reproduction and distribution in any medium for non-commercial purposes, provided the original author(s) are credited and the original publication in Refuge: Canada's Journal on Refugees is cited. 